\title{
An Experimental Study on Task-Based Interaction in Improving College Students’ English Speaking Ability
}

\author{
Bin Chen* \\ School of Foreign Language \\ Wuhan Institute of Technology \\ Wuhan, Hubei Province, China \\ e-mail: apple163@163.com
}

\author{
Yuanyuan Zhang \\ School of Foreign Language \\ Wuhan Institute of Technology \\ Wuhan, Hubei Province, China
}

\begin{abstract}
Nowadays, many college non-English majors' English speaking abilities can't meet the basic requirement of College English Curriculum Requirements. To solve the problem, taskbased interaction pedagogy was employed in college English speaking instruction. To probe the effect of the new teaching method, quasi-experimental design was adopted: the task-based interaction pedagogy was applied to College English Speaking instruction in the experimental class, while the conventional tasksupported approach was used in the control class. The experiment lasted for three months. Data of the pre-test and posttest were analyzed with SPSS software (19.0 edition). Results of the Independent-Sample $T$ test and Paired-Sample $T$ test were discussed. Findings showed that, compared with the tasksupported approach, the task-based interaction pedagogy was more effective in improving students' English speaking ability after the experiment, and interestingly, most students' English speaking abilities in the experimental class met the basic requirement of College English Curriculum Requirements, however, that of many students in the control class did not.
\end{abstract}

Keywords-College English speaking ability; task-based language pedagogy; task-supported approach; task-based interaction pedagogy

\section{INTRODUCTION}

In China, college non-English majors have to develop their English speaking abilities to meet the basic requirement of College English Curriculum Requirements. The basic requirements of college English speaking abilities for college non-English majors are as follows:

Students should be able to communicate in English in the course of learning, to conduct discussions on a given theme, to talk about everyday topics with people from English-speaking countries. They should be able to give, after some preparation, short talks on familiar topics with clear articulation and basically correct pronunciation and intonation. They are expected to be able to use basic conversational strategies in dialogue (Gaodeng jiaoyusi, 2007)[1].

However, most college non-English majors' English speaking abilities can't meet the basic requirement above. For, firstly, the conventional Task-supported approach can't provide authentic English speaking environment, or arouse students' interest and self-confidence in speaking English; secondly, students wouldn't like to open their mouth to speak English in class due to their limited English speaking abilities; thirdly, the class size of College English Speaking course are becoming larger and larger nowadays, and opportunities for students to speak English in class are becoming less and less. As a result, the effect of College English Speaking instruction is not as good as expected. To solve these problems, the present author adopted task-based interaction pedagogy to teach non-English majors College English Speaking course, in the expectation of improving students' English speaking abilities and meeting the basic requirement of College English Curriculum Requirements.

\section{LITERATURE REVIEW}

Since the implement of Bangalore Communicational Teaching Project (Prabhu, 1987)[2], task-based language pedagogy has developed into a prominent trend in second language instruction (Kumaravadivelu, 2006)[3]. Ogilvie \& Dunn(2010)[4] argue that, despite its theoretical appeal and research-based support, task-based language pedagogy still have somewhat limited influence on actual second language teaching practices in many contexts. Although the main component of task-based language pedagogy is "task", it has been defined in many different ways in literatures. Generally, researchers agree that the term "task" is language learning activity focused on meaning (Ellis, 2003[5]; Nunan, 2004[6]; Skehan, 1998[7]), that "task" involves a clear goal or outcome (Breen, 1987[8]; Prabhu, 1987[2]; Willis, 1996[9]), and that "task" reflects how to use language in authentic nonpedagogical contexts (Long, 1985[10]). There are differences in implementing "task" in language instructions, so Ellis (2003)[5] proposed the terms "task-based" and "tasksupported" as a way of distinguishing task-based interaction pedagogy from task-supported approach. Task-supported approach employs tasks primarily as ways in practicing linguistic forms which have been explicitly taught in class. Task-supported approaches usually use a "Presentation Practice - Production (PPP)" model, in which a particular linguistic form is first presented, then practiced through controlled activities such as drills, and finally used in language production. The PPP model assumes that language learning proceeds in a linear fashion, in which formal instruction is followed by activities to reinforce learning and promote automatization. While task-based interaction pedagogy invites students to act as language users rather than learners. So the explicit analysis of language structures and forms is given when difficulties arose during the completion of tasks. The 
theoretical basis of task-based interaction pedagogy is sociocultural theory. It premises that participants co-construct the 'activity' they engage in when performing a task, according to their own socio-history and locally determined goals (Ellis, 2000) [11]. Swain (2000) argues that the construction of tasks is needed to understand how learning arises out of performance [12]. Task-based interaction pedagogy views language learning as socially constructed process through interaction. For there was few experimental study on task-based interaction in improving college students' English speaking ability in China, the present author wanted to probe the effect of task-based interaction pedagogy used in College English Speaking instruction on improving college non-English majors' English speaking ability.

\section{DESIGN AND METHOD}

\section{A. Subjects}

For the convenience of the author's research, the present author adopted Quasi-experimental Designs. The subjects were 70 Chemistry majors who had to take the College English Speaking course instructed by the present author. They were college freshmen enrolled in September, 2013 at Wuhan Institute of Technology. They were divided randomly into two classes with 35 students per class in advance by enrollment officers when they were enrolled. All of them were Chinese coming from different provinces of China, and they studied English for 6 years at least. The subjects consisted of 42 (60\%) males and 28 (40\%) females. Their average age is 18 years old. The present author randomly decided Class One as the experimental class, and Class Two as the control class by picking lot.

\section{B. Research Questions}

The thesis focused on answering the following two research questions : (1) Can task-based interaction pedagogy applied to College English Speaking instruction improve the experimental class students' English speaking ability? (2) Compared with task-supported approach, can task-based interaction pedagogy applied to College English Speaking instruction be more effective in improving college students' English speaking ability?

\section{Instrument}

The instrument for the study was the pre-test and post-test paper on English speaking ability. The two sets of test paper (Test Paper One, Test Paper Two) were designed at the equal degree of difficulty, which had been used for testing freshmen's (college non-English majors) English speaking ability in the final examination of the first semester, in December, 2012. There are three kinds of tasks in each Test Paper, that is, (1) Reading a short story about 300 words and then retelling it within 5 minutes (30\% of the total score); (2) Role-play in pairs according to the given situation within 5 minutes (30\% of the total score); (3) preparing for a given theme and then making presentation on it within 5 minutes ( $40 \%$ of the total score). The total score of each Test Paper is 100 point. Test Paper One was used for pre-test before the experiment, and Test Paper Two were used for post-test after the experiment. The rules for grading the pre-test and post-test is to give a whole score on the accuracy, fluency, appropriateness of students' English speaking for each task, and then calculate the total score that a student gets in the three tasks.

\section{Research procedure}

The two classes were randomly assigned as the experimental class (Class One) and the control class (Class Two). From October, $6^{\text {th }}, 2013$ to December, $31^{\text {th }}, 2013$, the experiment lasted for three months. There were 2 periods (50 minutes per period) per week for College English Speaking instruction, during which the task-based interaction pedagogy was applied to College English Speaking instruction in Class One, and the traditional task-supported approach was applied to College English Speaking instruction in Class Two. Except for the different teaching approach to College English Speaking instruction, there were not any differences in text book, teaching material, topics for tasks in class and assignments after class. Before the experiment, the pre-tests for Class One and Class Two were implemented in Language Lab with the Test Paper One, students' performance were recorded respectively. After the experiment, the post-tests for Class One and Class Two were implemented in Language Lab with the Test Paper Two, students' performance were recorded. The present author and an assistant teacher listened to the students' test recordings together, and graded respectively according to the same rules of grading. In order to be as reasonable as possible, a student's score was the average of the two scores from us. The data of pre-test and post-test were collected and analyzed with SPSS software (19.0 edition). The results of Independent-Sample $\mathrm{T}$ test and Paired-Sample $\mathrm{T}$ test were explained and discussed, from which conclusion was drawn.

\section{DATA ANALYSIS}

Data of pre-test and post-test were entered into the computer. The specific data from the Independent-Sample $\mathrm{T}$ test and Paired-Sample T test were as follows:

(1) The results of the Paired-Sample T test between the pretest and the post-test for the experimental class (Class 1 ) is shown in the following tables:

TABLE I PAIRED SAMPLES STATISTICS FOR CLASS 1

\begin{tabular}{|l|l|l|l|l|l|}
\hline \multicolumn{2}{|c|}{} & Mean & N & $\begin{array}{l}\text { Std. } \\
\text { Deviation }\end{array}$ & Std. Error \\
\hline \multirow{2}{*}{ Class 1 } & Pre-test & 48.20 & 35 & 8.206 & 1.387 \\
\cline { 2 - 6 } & Post-test & 69.91 & 35 & 9.599 & 1.623 \\
\hline
\end{tabular}

TABLE II PAIRED SAMPLES STATISTICS FOR FOR CLASS 1

\begin{tabular}{|c|c|c|c|c|}
\hline \multicolumn{2}{|c|}{} & N & Correlation & Sig.S \\
\hline Class 1 & $\begin{array}{r}\text { Pre-test } \\
\text { \& Post-test }\end{array}$ & 35 & .932 & .000 \\
\hline
\end{tabular}

TABLE III PAIRED-SAMPle T TEST FOR ClASS 1

\begin{tabular}{|l|l|l|l|l|l|l|l|}
\hline \multirow{3}{*}{ Class 1 } & \multicolumn{3}{|l|}{ Paired Differences } & t & df & $\begin{array}{l}\text { Sig.(2-4 } \\
\text { ailed) }\end{array}$ \\
\cline { 3 - 5 } & Mean & $\begin{array}{l}\text { Std. } \\
\text { Devia- } \\
\text { tion }\end{array}$ & $\begin{array}{l}\text { Std. } \\
\text { Error } \\
\text { Mean }\end{array}$ & $\begin{array}{l}\text { 95\% } \\
\text { Confidence } \\
\text { Interval of the } \\
\text { difference }\end{array}$ & & \\
\cline { 1 - 1 } & & & Lower Upper & & \\
\hline Pre-test & & &
\end{tabular}




\begin{tabular}{|l|l|l|l|l|l|l|l|l|}
\hline- & -21.714 & 3.553 & .601 & - & - & - & 34 & .000 \\
Post- & & & & 22.935 & 20.494 & 3 & & \\
test & & & & & & 6. & & \\
& & & & & & 1 & & \\
& & & & & & 5 & & \\
\end{tabular}

As is shown in Table 2, r=0.932, $\mathrm{p}=0(\mathrm{p}<0.05)$, which indicated that there was significant difference. And from Table $3, t=-36.159, d f=34$, and $p=0(p<0.05)$, which also showed that there was significant difference. And from Table 1, the mean value of Class 1(the experimental class) in the pre-test was 48.20 (mean=48.20), and that of Class 1 in the post-test was 69.91 (mean=69.91), which showed that there was significant difference. So the performance of the experimental class in the post-test was greatly different from that of the pre-test.

(2) The results of the Paired-Sample T test between the pretest and the post-test for the control class (Class 2) is shown in the following tables:

TABLE IV PAIRED SAMPLES STATISTICS FOR CLASS 2

\begin{tabular}{|l|l|l|l|l|l|}
\hline \multicolumn{2}{|c|}{} & Mean & N & $\begin{array}{l}\text { Std. } \\
\text { Deviation }\end{array}$ & $\begin{array}{l}\text { Std. } \\
\text { Error }\end{array}$ \\
\hline \multirow{2}{*}{ Class 2 } & Pre-test & 48.57 & 35 & 7.678 & 1.298 \\
\cline { 2 - 6 } & Post-test & 57.51 & 35 & 7.812 & 1.320 \\
\hline
\end{tabular}

TABLE V PAIRED SAMPLES STATISTICS FOR ClASS 2

\begin{tabular}{|l|l|l|l|l|}
\hline \multicolumn{2}{|c|}{} & N & Correlation & Sig.S \\
\hline Class 2 & $\begin{array}{l}\text { Pre-test \& } \\
\text { Post-test }\end{array}$ & 35 & .978 & .000 \\
\hline
\end{tabular}

TABLE VI PAIRED-SAMPLE T TEST FOR ClASS 2

\begin{tabular}{|c|c|c|c|c|c|c|c|c|}
\hline \multirow[t]{2}{*}{ Class 2} & \multicolumn{5}{|c|}{ Paired Differences } & \multirow[t]{3}{*}{$t$} & \multirow[t]{3}{*}{$\overline{\text { df }}$} & \multirow{3}{*}{$\begin{array}{l}\text { Sig.(2- } \\
4 \\
\text { ailed) }\end{array}$} \\
\hline & \multirow[t]{2}{*}{ Mean } & \multirow[t]{2}{*}{$\begin{array}{l}\text { Std. } \\
\text { Deviation }\end{array}$} & \multirow[t]{2}{*}{$\begin{array}{l}\text { Std. } \\
\text { Error } \\
\text { Mean }\end{array}$} & \multicolumn{2}{|c|}{$\begin{array}{l}95 \% \text { Confidence } \\
\text { Interval of the } \\
\text { difference }\end{array}$} & & & \\
\hline \multirow{2}{*}{$\begin{array}{l}\text { Pre- } \\
\text { test } \\
\text { Post- } \\
\text { test }\end{array}$} & & & & Lower & Upper & & & \\
\hline & -8.943 & 1.644 & .278 & -9.508 & -8.378 & -32.183 & 34 & .000 \\
\hline
\end{tabular}

As is shown in Table 5, r=0.978, $\mathrm{p}=0(\mathrm{p}<0.05)$, which indicated that there was statistical difference. And from Table 6 , $\mathrm{t}=-32.183$, $\mathrm{df}=34$, and $\mathrm{p}=0(\mathrm{p}<0.05)$. These data also showed that there was statistical difference. And from Table 4, the mean value of Class 2 (the control class) in the pre-test was 48.57 (mean=48.57), and that of Class 2 in the post-test was 57.51(mean=57.51), which showed that there was significant difference. So the performance of the control class in the posttest was clearly different from that in the pre-test.

(3) The results of the Independent-Sample $T$ test for the pre-test before the experiment is shown in the following tables:

TABLE VII INDEPENDENT- SAMPLE STATISTICS FOR PRE-TEST

\begin{tabular}{|l|l|l|l|l|l|}
\hline & Class & N & Mean & $\begin{array}{l}\text { Std. } \\
\text { Deviation }\end{array}$ & $\begin{array}{l}\text { Std. } \\
\text { Error } \\
\text { Mean }\end{array}$ \\
\hline \multirow{2}{*}{ Pre-test } & 1 & 35 & 48.20 & 8.206 & 1.387 \\
\cline { 2 - 6 } & 2 & 35 & 48.57 & 7.678 & 1.298 \\
\hline
\end{tabular}

TABLE VIII INDEPENDENT-SAMPLE T TEST FOR PRE-TEST

\begin{tabular}{|c|c|c|c|c|c|c|c|c|c|}
\hline \multirow[t]{3}{*}{ Pre-test } & \multirow{2}{*}{\multicolumn{2}{|c|}{$\begin{array}{l}\text { Levene's } \\
\text { Test for } \\
\text { Equality of } \\
\text { variances }\end{array}$}} & \multicolumn{7}{|c|}{ t-test for Equality of Mean } \\
\hline & & & \multirow[b]{2}{*}{$t$} & \multirow[b]{2}{*}{ Df. } & \multirow[b]{2}{*}{$\begin{array}{l}\text { Sig.(2 } \\
-- \\
\text { tailed } \\
)\end{array}$} & \multirow[b]{2}{*}{$\begin{array}{l}\text { Mean } \\
\text { Differenc } \\
\text { e }\end{array}$} & \multirow[b]{2}{*}{$\begin{array}{l}\text { Std, } \\
\text { Error } \\
\text { Differenc } \\
\text { e }\end{array}$} & \multicolumn{2}{|c|}{$\begin{array}{l}95 \% \\
\text { Confidence } \\
\text { Interval of the } \\
\text { Difference }\end{array}$} \\
\hline & $\mathbf{F}$ & $\begin{array}{l}\text { Sig } \\
.\end{array}$ & & & & & & $\begin{array}{l}\text { Lowe } \\
\mathbf{r}\end{array}$ & $\begin{array}{l}\text { Uppe } \\
\mathbf{r}\end{array}$ \\
\hline $\begin{array}{l}\text { Equal } \\
\text { variance } \\
\text { s } \\
\text { assumed }\end{array}$ & $\begin{array}{l}.51 \\
9\end{array}$ & $\begin{array}{l}.47 \\
4\end{array}$ & $\begin{array}{l}- \\
.19 \\
6\end{array}$ & 68 & .846 & -.371 & 1.900 & $\overline{4} .162$ & 3.419 \\
\hline $\begin{array}{l}\text { Equal } \\
\text { varianc } \\
\text { es not } \\
\text { assu } \\
\text {-med }\end{array}$ & & & $\begin{array}{l}- \\
.19 \\
6\end{array}$ & $\begin{array}{l}67.70 \\
2\end{array}$ & .846 & -371 & 1.900 & $\overline{-}-162$ & 3.420 \\
\hline
\end{tabular}

As is shown in table 8, Levene $\mathrm{F}=0.519, \mathrm{P}=0.474(\mathrm{p}>0.05)$, which suggested that data in the row of "Equal variances assumed" were valid. And $t=-0.196, \mathrm{P}=0.846(\mathrm{p}>0.05)$, which showed that there was not significant difference. From Table 7, the Mean of Class 1 (the experimental class) is 48.20, and that of Class 2 (the control class) is 48.57 . So there were hardly differences.

(4) Results of the Independent-Sample T test for the posttest after the experiment is presented in the following tables:

TABLE IX INDEPENDENT SAMPLES STATISTICS FOR POST-TEST

\begin{tabular}{|l|l|l|l|l|l|}
\hline & Class & $\mathbf{N}$ & Mean & $\begin{array}{l}\text { Std. } \\
\text { Deviation }\end{array}$ & $\begin{array}{l}\text { Std. Error } \\
\text { Mean }\end{array}$ \\
\hline \multirow{2}{*}{ Post-test } & 1 & 35 & 69.91 & 9.599 & 1.623 \\
\cline { 2 - 6 } & 2 & 35 & 57.51 & 7.812 & 1.320 \\
\hline
\end{tabular}

TABLE $X$ InDEPENDENT-SAMPLE T TEST FOR POST-TEST

\begin{tabular}{|c|c|c|c|c|c|c|c|c|c|}
\hline \multirow[t]{3}{*}{ Pre-test } & \multirow{2}{*}{\multicolumn{2}{|c|}{$\begin{array}{l}\text { Levene's } \\
\text { Test for } \\
\text { Equality of } \\
\text { variances }\end{array}$}} & \multicolumn{7}{|c|}{ t-test for Equality of Mean } \\
\hline & & & \multirow[b]{2}{*}{$\mathrm{t}$} & \multirow[b]{2}{*}{ Df. } & \multirow[b]{2}{*}{$\begin{array}{l}\text { Sig. } \\
2- \\
\text { taile } \\
\text { d) }\end{array}$} & \multirow[b]{2}{*}{$\begin{array}{l}\text { Mean } \\
\text { Differen } \\
\text { ce }\end{array}$} & \multirow[b]{2}{*}{$\begin{array}{l}\text { Std, } \\
\text { Error } \\
\text { Differen } \\
\text { ce } \\
\end{array}$} & \multicolumn{2}{|c|}{$\begin{array}{l}95 \% \\
\text { Confidence } \\
\text { Interval of the } \\
\text { Difference }\end{array}$} \\
\hline & F & Sig & & & & & & $\begin{array}{l}\text { Lowe } \\
\mathrm{r}\end{array}$ & $\begin{array}{l}\text { Uppe } \\
\text { r }\end{array}$ \\
\hline $\begin{array}{l}\text { Equal } \\
\text { varianc } \\
\text { es } \\
\text { assume } \\
\text { d } \\
\end{array}$ & $\begin{array}{l}1.17 \\
6\end{array}$ & $\begin{array}{l}.28 \\
2\end{array}$ & 5.928 & 68 & .000 & 12.400 & 2.092 & 8.226 & $\begin{array}{l}16.57 \\
4\end{array}$ \\
\hline $\begin{array}{l}\text { Equal } \\
\text { varianc } \\
\text { es not } \\
\text { assu } \\
\text {-med }\end{array}$ & & & $\begin{array}{l}5.928 \\
6\end{array}$ & $\begin{array}{l}65.30 \\
4\end{array}$ & .000 & 12.400 & 2.092 & 8.223 & $\begin{array}{l}16.57 \\
7\end{array}$ \\
\hline
\end{tabular}

As is shown in table 10, Levene $\mathrm{F}=1.176, \mathrm{P}=0.282(\mathrm{p}>0.05)$, which suggested that the data in the row of "Equal variances assumed" were valid. And $t=5.928, P=0(P<0.05)$, which showed that there was significant difference. From Table 9, the mean value of Class 2 (the control class) is 57.51(mean=57.51), and that of Class 1 (the experimental class) is 69.91 (mean=69.91) in the post-test. So there was also great difference.

\section{RESUlts AND DisCUSSION}

As the results of Paired-Sample T test for the experimental class indicated that students' English speaking ability of the experimental class improved greatly after the experiment, which answered the first research question. That is, task-based interaction pedagogy applied to College English Speaking 
instruction can improve the experimental class students' English speaking ability. And the average score of their English speaking abilities is 69.91(Mean=69.91) in the post-test, which suggested that English speaking abilities of most students in the experimental class could meet the basic requirement of the College English Curriculum Requirements at the end of the first semester. Then, the teaching aim of College English Speaking course was realized at the end of the first semester. So the effect of task-based interaction pedagogy applied to College English Speaking instruction was good. Although the results of Paired-Sample T test for the control class suggested that students' English speaking ability of the control class improved a lot after the experiment, the average score of their English speaking abilities is 57.51 (Mean=57.51) in the posttest, which suggested that most students' English speaking abilities of the control class could not meet the basic requirement of the College English Curriculum Requirements at the end of the first semester. Then, the teaching aim of College English Speaking course was not realized well at the end of the first semester.

The results of the Independent-Sample $\mathrm{T}$ test for the pretest suggested that there were not any differences in students' English speaking test scores of the experimental class(Mean=48.20) and the control class (Mean=48.57)in the pre-test before the experiment. That is, students' English abilities of the experimental class and the control class are nearly at the same level before the experiment, and most students' English speaking abilities were limited, which could not meet the basic requirement of the College English Curriculum Requirements in the beginning of the first semester. The results of Independent-Sample T test for post-test showed that there were significant differences in students' English speaking test scores of the experimental class and the control class after the experiment. That is, students' English speaking abilities of the experimental class (Mean=69.91) outperformed that of the control class(Mean=57.51) in the post-test after the experiment. For there was not any differences except that, during the three months' experiment, the task-based interaction pedagogy was adopted in College English Speaking instruction for the experimental class, and the traditional task-supported approach was used in College English Speaking instruction for the control class. Therefore, the possible reasons were that the task-based interaction pedagogy used in college English Speaking instruction was more effective in improving students' English speaking ability than that of the task-supported approach. So the results of Independent-Sample $T$ test answered the second research question. That is, compared with task-supported approach, task-based interaction pedagogy applied to College English Speaking instruction was more effective in improving college students' English speaking ability.

\section{CONCLUSION}

Based on the results of the experiment, the major findings coming from the present study can be summarized as follows: task-based interaction pedagogy used in College English Speaking instruction can improve the experimental class students' English speaking ability; and compared with tasksupported approach, task-based interaction pedagogy applied to College English Speaking instruction have more significant effect in improving college students' English speaking ability; Interestingly, after the experiment, most students' English speaking abilities of the experimental class met the basic requirement of the College English Curriculum Requirements, while most students' English speaking abilities of the control class could not meet the basic requirement of the College English Curriculum Requirements.

However, the present research had limitations in its small sample size, too short period of time and so on. So some suggestions are proposed for further research, Firstly, larger sample size and longer period of time are included. Secondly, class observation and interview accompanied with experiment could obtain more fruitful findings.

\section{ACKNOWLEDGMENT}

This work was supported by Hubei Provincial Department of Education under Grant 13d044 and Wuhan Institute of Technology under Grant X2013031.

\section{REFERENCES}

[1] Gaodeng jiaoyusi, College English Curriculum Requirements, Shanghai, China: Shanghai foreign language education press, 2007, pp. 25-26.

[2] N. S. Prabhu, Second language pedagogy, Oxford: Oxford University Press, 1987, pp.22-80.

[3] B. Kumaravadivelu, "TESOL methods: Changing tracks, challenging trends,” TESOL Quarterly, vol.40, No.1, pp. 59-82, Mar. 2006.

[4] G. Ogilvie, W. Dunn, “Taking teacher education to task: Exploring the role of teacher education in promoting the utilization of task-based language teaching,” Language Teaching Research, vol. 14, No.2, pp. 161-181, June, 2010.

[5] R. Ellis, Task-based language learning and teaching, Oxford: Oxford University Press, 2003, ch.4, pp.103-126.

[6] D. Nunan, Task-based language teaching, Cambridge: Cambridge University Press, 2004, pp.40-138.

[7] P. Skehan, A cognitive approach to language learning, Oxford: Oxford University Press, 1998, pp.129-132.

[8] M. Breen, "Contemporary paradigms in syllabus design," Language Teaching, vol. 20, pp. 235-250, oct.1987.

[9] J. Willis, A framework for task-based learning, Harlow: Addison Wesley Longman, 1996, pp.94-115.

[10] M. H. Long, "Input and second language acquisition theory," In S. Gass \& C. Madden (Eds.), Input and second language acquisition, Rowley, MA: Newbury House, 1985, pp.377-393.

[11] R. Ellis, “Task-based research and language pedagogy," Language Teaching Research, vol. 4, No.3, pp. 193-220, July, 2000.

[12] M. Swain, "The output hypothesis and beyond: Mediating acquisition through collaborative dialogue”, In J. P. Lantolf (Ed.), Sociocultural theory and second language learning, Oxford: Oxford University Press, 2000, pp. 97-114. 